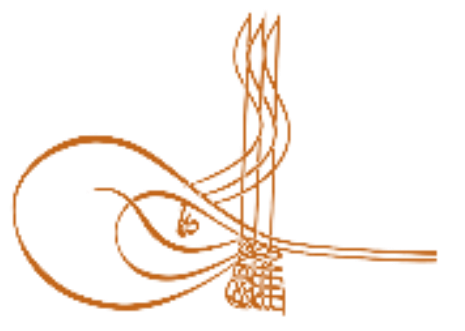

www.turkishstudies.net/turkishstudies
Turkish Studies

eISSN: $1308-2140$

Research Article / Araștırma Makalesi

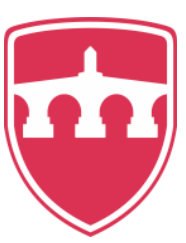

INTERNATIONAL

BALKAN

UNIVERSITY

Sponsored by IBU

\title{
Montessori Yönteminin Okul Öncesi Dönemdeki Çocukların Bilimsel Süreç Becerilerine Etkisinin İncelenmesi*
}

\author{
The Research of the Montessori Method's Effects to Pre-School Term Children's Scientific Process \\ Skills
}

Kübra Üstündağ ${ }^{* *}$ - Büşra Ergin ${ }^{* * *}$

\begin{abstract}
This study was carried out to investigate the effect of Montessori Method on the scientific process skills of 48-66 months old children who are attending the preschool education institution. The dependent variable of the research is the scientific process skills of the children attending pre-school education, while the independent variable is the Montessori Method. Data related to the study were collected in the 2017-2018 academic year. The study group of the research was trained in Ihsan Dogramaci Practice Kindergarten and Mevlana Kindergarten; it consisted of 46 children, including 22 experiments and 24 control groups. In the research, the Basic Skills Scale and Personal Information Form for Preschool Students was used to determine the scientific process skill levels of preschool children as a data collection tool. The data obtained were analyzed by $\mathrm{t}$ test in dependent groups, $\mathrm{t}$ test in independent groups and Mann-Whitney $\mathrm{U}$ test techniques. As a result of the analyzes, The Ministry of National Education with the pretest scores of the Basic Skill Scale of the experimental group children who received pre-school education with Montessori Method. It was concluded that the pre-test mean scores of the Basic Skill Scale of the control group children who received preschool education by using the Preschool Education Program were similar. Primary Skill Scale post-test mean scores of the experimental group children who received pre-school education with Montessori Method, M.E.B. It is observed that the Basic Skill Scale of the control group children who received preschool education by using the Preschool Education Program is higher than the post-test mean scores. As a result, it has been determined that Montessori Education Program has made a positive contribution in the development of scientific process skills of preschool children. In addition, it was concluded that Montessori Education Program is more effective in acquiring and supporting the scientific process skills of children compared to M.E.B Preschool Education Program.
\end{abstract}

\footnotetext{
${ }^{*}$ Bu çalışma, Necmettin Erbakan Üniversitesi Eğitim Bilimleri Enstitüsünde hazırlanan yüksek lisans tez çalışmasından üretilmiştir.

** Öğretmen, MEB

Teacher, Republic of Turkey Ministry of National Education

ORCID 0000-0002-3294-5688

kubra.kayhan@hotmail.com

**** Dr. Öğr. Üyesi, Selçuk Üniversitesi, Eğitim Fakültesi, Temel Eğitim Bölümü

Asst. Prof. Dr. Selcuk University, Faculty of Education, Departmant of Basic Education

ORCID 0000-0001-5177-7096

busra.ergin@selcuk.edu.tr

Cite as/ Atıf: Üstündağ, K., Ergin, B. (2020). Montessori yönteminin okul öncesi dönemdeki çocukların bilimsel süreç becerilerine etkisinin incelenmesi, Turkish Studies, 15(2),1483-1498. https://dx.doi.org/10.29228/TurkishStudies.39718

Received/Geliş: 11 November/Kasım 2019

Accepted/Kabul: 25 April/Nisan 2020

Copyright $\subset$ MDE, Turkey
} 
Structured Abstract: Curious by nature and eager to explore, early childhood period is the best time to introduce the child to science. Conscious referrals to the child and positive experiences of the child in this period will affect the child's relationship with science in the future. To encountering an enriched stimulating environment based on the process of learning by doing helps children make better observations and discoveries, and use scientific skills such as recording data, extracting and interpreting data.

Developing critical scientific process skills for early childhood acquisition is one of the skills that qualified science activities are planned for preschool children. In addition to developing scientific process skills (observation, classification, communication, measurement, estimation, conclusion and comparison) of children through science activities, it is also aimed to teach children that the world is worth exploring, researching and learning and contributing to the development of a positive attitude towards science.

The goals of early childhood science education can be achieved by providing effective science learning experiences to children. In this context, The Ministry of National Education 2013 Preschool Education Program; to concentrate attention on children, to wonder, to observe, to examine, to relate to science issues by moving from daily life, to solve every problem encountered in life, to use scientific methods, to understand the world we live in, aimed to develop the right attitudes towards their environment. Preschool teachers play an important role in providing children with rich and effective science learning experiences, and in developing correct attitudes towards the environment.

Today, the discussions about the importance of meeting the children in an early stage with enriched stimulating environment and activities organized according to a specific plan have been replaced by studies on improving and expanding the quality of preschool education. Thus, preschool education programs began to diversify over time. These educational programs, which are generally based on a specific theoretical approach, sometimes focus on the social development of children and sometimes on the cognitive development of children. These models include advocating that children learn in an environment independent absorbent mind thanks to Montessori model in Turkey and is one of the models that are widespread in the world. Montessori emphasizes the importance of the experiences gained from an early age in order for children to understand the universe they live in, first of all to realize their own place, to feel belonging and to acquire and develop basic knowledge about ecological life.

The findings of recent research show that the Montessori Method is an effective method to support children's developmental areas. The purpose of this research is to examine the contribution of Montessori Method to the development of scientific process skills of preschool children and to examine the differences between preschool education program of MEB and Montessori Education Program in supporting the scientific process skills of preschool children.

The population of the study consists of 48-66 months old children attending preschool education institutions in Konya in 2017-2018 academic year.

The study group consisted of 22 children studying Montessori in Selçuk University Ihsan Dogramaci Application Kindergarten and MEB Preschool Education Program 24 children were selected by appropriate sampling method from the universe by paying attention to the fact that they did not have Montessori education before, they were between 48-66 months and showed normal development.

In the study, a personal information form was used to obtain information about children and their parents who were included in the study group and the Basic Skill Scale for Preschool Students developed by Aydogdu and Karakus (2017) was used to determine the scientific process skill levels of the children.

The scores obtained from the Basic Skills Scale for Preschool Students, which are used to measure the scientific process skills, were tested for normal distribution of data from parametric test assumptions, homogeneity of variances, and $n \geq 20$ statistically. After the analysis, it is observed that the data shows normal distribution. Therefore, parametric tests were used to measure the statistical differentiation of experimental and control groups. According to the gender variable, non-parametric tests were used to evaluate the statistical differentiation of the groups because the difference between the pretest and posttest mean scores of the experimental and control group children, although the data was normally distributed and the variances were homogeneous, the sample size was small (since it did not provide the $n \geq 20$ precursor). Descriptive statistical techniques (frequency, arithmetic mean, percentage, standard deviation) were used for data analysis. In order to determine whether the Montessori education program of the children affected the scientific process skills of 
the children in the experimental group, the means of the difference between the pre-test and post-test scores of the experimental and control groups were compared with the t-test for independent groups. After the Montessori training program given to the experimental group children, the difference between the mean scores of pre-test and post-test of scientific process skills was tested with paired t test. Mann-Whitney U test was used to determine the difference between the pretest and posttest mean scores of the children in the experimental group according to the gender variable. The same procedure was repeated among the children in the control group.

According to the findings of the study, there was no significant difference between the pretest scores of the experimental group and the control group, but there was a significant difference between the posttest mean scores. According to the research findings, the difference between the pre-test and post-test mean scores of the children in the experimental group was significant, whereas there was no significant difference between the pre-test and post-test mean scores of the children in the control group. Research findings are consistent with the findings of Buyuktaskapu (2010), Sahin, Guven and Yurdatapan (2011), Ozkan (2015), Tekerci (2015), Toprakkaya (2016) and Yagc1 (2016). This finding is that the programs prepared to gain the scientific process skills at an early age are effective and permanent in providing children with these skills.

When the effect of gender variable on scientific process skills was examined, there was no significant difference between the pre-test mean scores of the children in the experimental group, whereas the post-test mean scores of the male students were found to be significantly higher than the mean scores of the female students. When the pre-test mean and post-test mean scores of the children in the control group were compared, no significant difference was found between the mean scores. It is possible to come across different results in the related literature.

In the light of the findings, it is seen that Montessori Education Program has a positive effect on the development of scientific process skills, but the lack of scientific research on whether or not it develops scientific process skills and makes it more meaningful in terms of the results of this study and the obtained data.

The findings which is inferred from the research, the following suggestions are presented; the findings which is inferred

1. When the literature is examined, it is seen that there are not enough studies examining the effect of Montessori Method on scientific process skills in preschool period. New studies on this subject may be suggested.

2. In this study, the effect of Montessori Education Method on scientific process skills of preschool children was examined. The impact of different programs on scientific process skills can be examined.

3. Findings can be evaluated by applying similar studies with different age groups in preschool period.

4. New studies can be developed by developing new measurement tools related to the research.

5. The Montessori method can be evaluated in the current preschool education curriculum to contribute to the enrichment of the program.

6. Based on the Montessori education philosophy, individual or institution-based educational activities can be organized for teachers working in preschool education institutions. As a result of the trainings given, teachers can be given the opportunity to give more place to individualized education by considering the individual characteristics of the children as in the Montessori Method.

7. In this study, it was concluded that Montessori method had a positive effect on the development of scientific process skills. By including follow-up studies in future researches, the results of Montessori training method can be examined in depth.

8. In-service training seminars can be given to pre-school education teachers to develop and support children's scientific process skills. Montessori Education Method and materials can also be included in these seminars.

9. Resources can be organized that provide examples of activities that pre-school teachers can use to support scientific process skills based on the Montessori Education Method to raise awareness of children about scientific process skills development and to increase their knowledge of the method and to be a guide. 
Keywords: Pre-school Education, Education, Educational Program, Approach, Model, Scientific Process Skills, Montessori Method

Öz: Bu çalışma, Montessori Yöntemi’nin okul öncesi eğitimi kurumuna devam etmekte olan 48-66 ay çocuklarının, bilimsel süreç becerilerine etkisini incelemek amacıyla yapılmıştır. Araştırmanın bağımlı değişkeni okul öncesi eğitime devam eden çocukların bilimsel süreç becerileri iken bağımsız değişkeni Montessori Yöntemi'dir. Çalışmaya ilişkin veriler, 2017-2018 eğitim-öğretim yılında toplanmıştır. Araştırmanın çalışma grubunu, İhsan Doğramacı Uygulama Anaokulu ve Mevlana Anaokulu'nda eğitim alan; 22 deney, 24 kontrol grubu olmak üzere 46 çocuk oluşturmuştur. Araştırmada veri toplama aracı olarak, okul öncesi çocuklarının bilimsel süreç beceri düzeylerini belirlemek amacıyla, Okul Öncesi Öğrencilerine Yönelik Temel Beceri Ölçeği ve Kişisel Bilgi Formu kullanılmıştır. Elde edilen veriler bağımlı gruplarda t testi, bağımsız gruplarda $t$ testi ve Mann-Whitney $U$ testi teknikleriyle analiz edilmiştir. Analizler sonucunda, Montessori Yöntemi ile okul öncesi eğitim alan deney grubu çocuklarının Temel Beceri Ölçeği ön test puan ortalamaları ile M.E.B. Okul Öncesi Eğitim Programı kullanılarak okul öncesi eğitim alan kontrol grubu çocuklarının Temel Beceri Ölçeği ön test puan ortalamalarının benzer olduğu sonucuna ulaşılmıştır. Montessori Yöntemi ile okul öncesi eğitim alan deney grubu çocuklarının Temel Beceri Ölçeği son test puan ortalamaları, M.E.B. Okul Öncesi Eğitim Programı kullanılarak okul öncesi eğitim alan kontrol grubu çocuklarının Temel Beceri Ölçeği son test puan ortalamalarından daha yüksek olduğu gözlenmektedir. Sonuç olarak, Montessori Eğitim Programının okul öncesi dönem çocuklarının bilimsel süreç becerilerinin geliştirilmesinde pozitif yönlü bir katkı sağladığı saptanmıştır. Ayrıca Montessori Eğitim Programının, M.E.B Okul Öncesi Eğitim Programına kıyasla çocukların bilimsel süreç becerilerinin kazanımında ve desteklenmesinde daha etkili olduğu sonucuna ulaşılmıştır.

Anahtar Kelimeler: Okul Öncesi Eğitim, Eğitim, Eğitim Programı, Yaklaşım, Model, Bilimsel Süreç Becerileri, Montessori Yöntemi.

\section{Giriş}

Okul öncesi dönem gelişimin yoğun ve hızlı yaşandığı, çocuğun çevresini araştırıp tanımaya çalıştığı, erken akademik becerilerin kazanıldığı dönemdir. Bu dönemde kazanılan erken akademik becerilerin, çocuğu geleceğe hazırladığı ve gelecekteki başarılarının da zeminini oluşturduğu görülmektedir (Kefi, Çeliköz ve Erişen, 2013). Bununla beraber okul öncesi eğitim merkezlerinde fen eğitiminin kalitesini nasıl yükseltilebileceği de araştırmacılar ve eğitimcilerin önemle üzerinde durduğu bir konu olmuştur.

Doğası gereği meraklı ve keşfetmeye istekli olunan erken çocukluk yılları çocuğu bilim ile tanıştırmada en uygun zamandır. Bu dönemde çocuğa bilinçli olarak yapılacak yönlendirmeler ve çocuğun olumlu deneyimleri ileride çocuğun bilimle olan ilişkisini etkileyecektir. Yaparak yaşayarak öğrenme süreci temel alınarak zenginleştirilmiş uyarıcı çevreyle karşılaşması, çocukların daha iyi gözlem ve keşifler yapmasına, veri kaydetme, verilerden çıkarım yapma ve yorumlama gibi bilimsel becerileri kullanmalarına yardımcı olur (Ayvacı, 2010; Büyüktaşkapu, 2010; Kula, 2011; Kefi, Çeliköz ve Erişen, 2013)

Modern fen öğretiminin temel amaçlarından biri de, içinde yaşadığımız çağın gereği araştırmacı, gözlemci, gündelik hayatla fen konuları arasında bağıntı kurabilen, yaşamı süresince karşılaştığı bütün problemleri çözmede bilimsel metodu kullanabilen, bir bilim adamının bakış açısını anlayabilen bireyler yetiştirmektir (Tan ve Temiz, 2003). Bilim insanları gibi doğayı anlamlandırmak maksadıyla sorular soran ve sorularına yanıt aramak üzere erken çocukluktan itibaren araştırmalar yapan çocuk, ilköğretim yaşamına kazandığı bu tecrübelerle ve birçok konuyla ilgili ön bilgilere sahip olarak başlamaktadır. Çocukların mevcut bilgileri doğa, çevre ve yaşamla ilgili konuları içermesi nedeniyle okul öncesi dönemde fen etkinliklerine yeterli süre tanınmalıdır. Yapılan aktivitelerde asıl hedef, çocukların sadece bilgi kazanımını sağlamak olmayıp, çocukların var olan merakını gidererek, çalışmalarında bilimsel süreç becerilerini kullanmalarını desteklemek 
olmalıdır. Bu şekilde, bilimi yaparak yaşayarak öğrenmelerine imkan tanınmaktadır (Aktaş Arnas, 2003; Büyüktaşkapu, Çeliköz ve Akman, 2012). Ülkemizde erken çocukluk eğitiminde, her kurumun kendi okullarının ve çocuklarının özelliklerine göre belli bir yaklaşım çerçevesinde kendilerine ait bakanlıkça onaylanmış bir program izlemeleri, belirlenmiş ulusal kalite standartlarının olmaması nedeniyle anaokulları ve anasınıflarında program birlikteliğinin olmaması onaylanmış olan programın uygulanmasında öğretmenlerin öğretme stilleri ve konuyu ele alma şekilleri, çocukların hazır bulunuşlukları, öğrenme hızlarının değişim göstermesi gibi sayısız faktör okul öncesi eğitimin kalitesini etkilemektedir. okul öncesi eğitim programlarını etkilemektedir. Bu sebeple fen eğitiminde çocukların ulaşması istenilen hedefler kurumdan kuruma değişiklik gösterebilmektedir (Akman, Üstün ve Güler, 2003).

Erken çocuklukta kazanılması kritik önem taşıyan bilimsel süreç becerilerinin geliştirilmesi okul öncesi dönem çocukları için planlanan nitelikli fen etkinliklerinin kazandırmaya çalıştığı beceriler arasındadır. Fen etkinlikleriyle çocukların bilimsel süreç becerilerinin (gözlemleme, sınıflama, iletişim, ölçme, tahmin etme, sonuç çıkarma ve karşılaştırma) geliştirilmesinin yanı sıra çocuklara, dünyanın keşfedilmeye, araştırmaya ve öğrenmeye değer olduğunu kavratmak ve bilime yönelik olumlu tutum geliştirmesine katkı sağlamakta amaçlanmaktadır (Akman, Üstün ve Güler, 2003; Murpy ve Smith; 2014; Saçkes, Akman ve Trundle, 2012; Aktaş Arnas, 2002; Kuru ve Akman, 2017).

Temel süreç becerileri bilimsel araştırma yapabilmenin temelini oluşturan, her bireyin bilimin doğasını kavrayarak yaşam kalitesini artırmak için günlük hayattın bütün aşamalarında kullanabileceği becerilerdir. Amerikan Fen Eğitiminin Geliştirme Komisyonu (AAAS) ve çoğu araştırmacının bilimsel süreç becerileri ile ilgili sınıflamaları incelendiğinde bilimsel süreç becerilerinin "temel beceriler" ve "birleştirilmiş beceriler" olarak iki aşamada ele aldıkları görülmektedir (Howe ve Jones, 1998; Padilla, Okey ve Garrard,1984; Wilke ve Straits 2005; Brotherton ve Preece 1995; Martin, Sexton ve Gerlovich, 2002; Akt. Büyüktaşkapu, 2010). Temel bilimsel süreç becerileri Tablo 1'de tanımlanmaktadır.

Tablo 1: Temel Bilimsel Süreç Becerileri

\begin{tabular}{|c|c|}
\hline Temel Beceriler & Açıklamalar \\
\hline Gözlem yapma & $\begin{array}{l}\text { Duyu organlarından biri veya birkaçını ya da duyu organlarının hassasiyetini artıran } \\
\text { değişik araç gereçleri kullanarak çevrede gerçekleşen olayları anlamlandırma, } \\
\text { herhangi bir konuya odaklanma ve konu hakkında bilgi kazanmayı içeren en temel } \\
\text { bilimsel süreç becerisidir (Alabay, 2013). }\end{array}$ \\
\hline Sinıflandırma & Nesnelerinin benzer ve farklı yönlerini gruplama becerisidir (Büyüktaşkapu, 2012). \\
\hline Ölçme & $\begin{array}{l}\text { Ölçülecek nesnenin gözlenebilir özelliklerini fark edip uygun araçlar kullanarak } \\
\text { değişkenin niceliğini ve boyutlarını keşfetme, sayısal olarak ifade etme sürecidir } \\
\text { (Alabay, 2013). }\end{array}$ \\
\hline $\begin{array}{l}\text { İletişim / Verileri } \\
\text { Kaydetme }\end{array}$ & $\begin{array}{l}\text { Verileri kaydetme, olay veya nesnelerle ilgili elde edilen bilgileri bilimsel biçimde } \\
\text { düzene sokma becerisidir. İletişim becerisiyse olay ve nesnelerden toplanan bulgular } \\
\text { doğrultusunda oluşan bilgileri çevreye sunmadır (Büyüktaşkapu, 2010; Alabay, } \\
\text { 2013). }\end{array}$ \\
\hline Tahmin Etme & $\begin{array}{l}\text { Bulunan verilere bakılarak ve geçmişteki deneyimlerden yola çıkarak bir olayın } \\
\text { gelecekteki sonucu hakkında yargıda bulunma becerisidir (Bağcı-Kılıç, 2003). }\end{array}$ \\
\hline Sonuç Çıkarma & $\begin{array}{l}\text { Bireyin gözlemler ve önceki bilgilere dayanarak bir şeyin neden olduğuna dair en } \\
\text { iyi tahminidir (Büyüktaşkapu, 2010). }\end{array}$ \\
\hline
\end{tabular}


Erken çocukluk dönemi bilim eğitiminin hedeflerine, çocuklara etkili bilim öğrenme deneyimleri sağlanarak ulaşılabilir (Ayvac1, 2010). Bu bağlamda hazırlanan, 2013 yılı Okul Öncesi Eğitimi Programı; çocuklara dikkatini yoğunlaştırmayı, merak etmeyi, gözlemlemeyi, incelemeyi, günlük yaşamdan hareket ederek fen konularıyla ilişkilendirmeyi, hayatta karşılaştığı her problemi çözmede bilimsel yöntemleri kullanabilmeyi, yaşadığımız dünyayı anlamayı sağlamayı, çevrelerine yönelik doğru tutumlar geliştirebilmelerini amaçlamıştır. Çocuklara zengin ve etkili bilim öğrenme deneyimleri sağlamada okul öncesi öğretmenlerine önemli rol düşmektedir (Akman, Üstün ve Güler, 2003; Ünal ve Akman, 2006; Kılıç, 2010).

Çocukların okul öncesi dönemde fen eğitiminin genel amaçlarından olan bilimsel düşünme, bilimsel süreç becerilerini kazanma ve çevreye karşı doğru tutumlar geliştirebilmelerinde aileleri kadar öğretmenlerinde önemli rolü vardır. Okul öncesi öğretmen adaylarının bilim öğrenimi ve öğretimine yönelik deneyimleri, öğrenimleri esnasında aldıkları "Fen Eğitimi" dersi ile sınırlı kalmaktadır. Bu deneyim öğretmen adaylarına erken çocukluk döneminde bilim eğitiminin önemi konusunda farkındalık yaratmak açısından önemli olsa da, nitelikli bilim etkinliği hazırlamada, kendilerini yeterli hissetme ve bilimsel alan bilgisi ile donatma açısından yetersiz kalmaktadır (Ayvac1, Devecioğlu ve Yiğit, 2002; Özbey ve Alisinanoğlu, 2009).

Nitelikli bir bilim eğitim programının uygulayıcısı olan öğretmenler, çocuklara bol uyarıcılı bilim alanları oluşturulmalı ve bilim öğrenmenin amaçlarını doğrudan destekleyen keşif materyalleri ve keşifleri gerçekleştirebilecekleri alanlar sunmalıdır. Bu alanlarda çocukların keşiflerini özgürce tartışabilecekleri ve öğrenmelerini paylaşabilecekleri, karşılaştıkları deneyimlerle bilimsel süreç becerilerini yapılandırabilecekleri ortamlar hazırlamak iyi bir bilim uygulayıcısını öngörmektedir (Kefi ve Uslu, 2015; Tekerci, 2015).

Günümüzde çocukların erken dönemde zenginleştirilmiş uyarıcı ortamla ve belli bir plana göre düzenlenmiş etkinliklerle karşılaşmasının önemini konu alan tartışmalar yerini okul öncesi eğitiminin kalitesinin artırılması ve yaygınlaştırılması konusu ile ilgili çalışmalara bırakmıştır (Büyüktaşkapu, Çeliköz ve Akman, 2012; Toprakkaya, 2016). Böylelikle okul öncesi eğitim programları zamanla çeşitlenmeye başlamıştır. Genellikle belirli bir teorik yaklaşımı taban alarak oluşturulan bu alternatif programlar, kimi zaman çocukların sosyal gelişimine yoğunlaşırken, kimi zamansa çocukların bilişsel gelişimine yoğunlaşmaktadır. Alternatif programlar oluşturulurken dikkat edilmesi gereken önemli hususlardan biri programın çocukların gelişim alanlarını bütünüyle desteklerken çocuklar arasındaki başkalıklarında gözetiliyor olmasıdır (Arı, 2005).

Gittikçe daha benimsenmiş şekilde kullanılmaya başlanılan, çocukların gelişimsel özelliklerini destekleyen ve başkalıklarını gözeten bu eğitim modelleri birbirinden farklı program içeriklerinin olması gerektiğini savunsalar da hepsinin esas ilkesi, çocukların gizil güçlerini etkin şekilde kullanmalarını sağlayacak bir yapılandırma oluşturmaktır (Şahintürk, 2012). Bu modeller arasında çocuğun özgür bir ortamda emici zihni sayesinde öğrendiğini savunan Montessori eğitim modeli Türkiye'de ve Dünya'da yaygınlaşan modellerin başında gelmektedir.

Dünya genelinde Montessori yaklaşımının daha fazla tercih edilmesinin sebebi ise; Montessori yönteminin çocuklara kaliteli bir eğitim programı sunması, çocuğu merkeze alması, kendiliğinden öğrenme ve bağımsızlık imkanı tanıyan sistemli ve güzel duygular uyandıran bir ortama sahip olması, eğitime erken yaşlarda yoğunlaşılması, eğitimi bireyselleştirmesi ve eğitim sürecinde aileyi de dahil eden etkinlikler içeriyor olmasıdır (Morrison,1998; Akt. Temel ve Toran, 2013).

Maria Montessori'nin hiçbir insanın bir diğeri tarafından eğitilemeyeceği görüşüne dayanarak oluşturduğu yöntem çocuğu merkeze alan bir eğitim sistemi olması sebebiyle öğretmenin rolü geleneksel eğitime kıyasla tamamen değişmiştir. Geleneksel eğitim yönteminde öğretmen öğretici rolünde olup, öğrenmeyi kontrol eden, programı ve konuları belirleyen, sessizliğe önem veren sadece sözel anlatım yöntemini kullanan otoriter bilgi kaynağıyken Montessori yönteminde 
yönlendirici, dikkatli bir gözlemci ve kayıt tutucu, rol model, çevre düzenleyici rolünü üstlenir. Bu yöntemde çocuk bilgiyi öğretmenden doğrudan değil çevreden deneyimleyerek almaktadır (Özdağ, 2014).

Montessori, insanların kozmik planlarını gerçekleştirebilecek tek canlı olduğunu ve dünyada bulunan her şey için mesuliyet alması gerektiğini belirtir. Bu hissin her şeyden önce erken dönemden başlayarak uyandırılması gerektiğini anlatmaktadır. Bu nedenle Montessori yaklaşımında bilimsel olgular herhangi birinin desteği olmadan, kültür, zaman, doğa ve mekan ile ilişkilendirilerek öğretilmektedir. Montessori yaklaşımında fen bilimleri alanındaki aktivitelerde dört elementin (su, ıșık, hava ve ateș), mıknatıs ve elektrikle ilgili materyallerin kullanıldığı bilinmektedir. Montessori, çocukların yaşamıș olduğu evreni anlayabilmesi adına öncelikle kendi yerini fark etmesi, aitlik hissetmesi ve ekolojik hayatla ilgili temel olan bilgileri edinerek geliştirmesinde, bilimle ilgili küçük yaşlardan itibaren edindikleri deneyimlerin önemini vurgulamaktadır. Yapılan bu çalışmaların farkındalığg artırarak çocukların bilimle ilgili gizil süreçlerini ortaya çıkardığı görülmektedir (Büyüktaşkapu, 2012; Grazzini,2013; O'Donnell, 2014; Akdeniz, 2017).

Son yıllarda yapılan araştırmaların bulguları, Montessori Yönteminin çocukların gelişim alanlarını desteklemede etkili bir yöntem olduğunu göstermektedir. $\mathrm{Bu}$ araştırmanın amacı; Montessori Yönteminin, okul öncesi dönem çocuklarının bilimsel süreç becerilerinin gelişimine katkısını incelemek ve hâlihazırda uygulanan MEB Okul Öncesi Eğitim Programı ile Montessori Eğitim Programının okul öncesi dönem çocuklarının bilimsel süreç becerilerini desteklemedeki farklılıklarını belirlemeye çalışmaktır.

\section{Yöntem}

\section{Araştırma Deseni}

$\mathrm{Bu}$ araştırmada neden-sonuç ilişkilerini belirlemeye çalışmak amacı ile öntest-sontest kontrol gruplu deneme modeli kullanılmıştır. Ön test son test kontrol gruplu modelde yansız atama ile oluşturulmuş deney ve kontrol grubu olarak iki grup bulunur. Her iki grupta da deney öncesi ve deney sonrası ölçmeler yapılır (Karasar, 2009).

Araştırmanın ön test verileri 2017-2018 eğitim öğretim yılının Kasım ayında, son test verileri ise Mart ayında deney ve kontrol grubu çocuklarından elde edilmiştir. Araştırmada, deney grubuna seçilen çocuklara kendi öğretmenleri tarafından Montessori eğitim yöntemi uygulanmıştır. Kontrol grubu çocuklarına ise kendi öğretmenleri tarafindan Milli Eğitim Bakanlığg Okul Öncesi Eğitim Programı uygulamasına devam edilmiştir. Desende bağımlı değişken, okul öncesi eğitim kurumlarına devam eden 48-66 ay arasında yer alan çocukların "bilimsel süreç becerileri" iken, çocukların bilimsel süreç becerileri üzerine etkisi incelenen bağımsız değişken ise "Montessori Yöntemi” dir. Araştırma deseninin sembolik görünümü aşağıdaki şekil ile açılanabilir;

Ön Test

$\begin{array}{lllll}\text { GD } & \mathrm{R} & \mathrm{O} 1 & \mathrm{X} 1 & \mathrm{O} 3 \\ \mathrm{GK} & \mathrm{R} & \mathrm{O} 2 & & \mathrm{O} 4\end{array}$

\section{Son Test}

$\mathrm{O} 4$

GD: Montessori Yöntemiyle okul öncesi eğitim alan deney grubunu

GK: Milli Eğitim Bakanlığı Okul Öncesi Eğitim Programı'na göre okul öncesi eğitim alan kontrol grubunu

R: Deneklerin gruba yansız atandığını

O1 ve 03: Deney grubunun ön test ve son test ölçümlerini

O2 ve 04: Kontrol grubunun ön test ve son test ölçümlerini 
X1: Deney grubuna uygulanan bağımsız değişken (Montessori Yöntemi) (Karasar, 2009).

\section{Çalışma Grubu}

Araştırmanın çalışma grubunu 2017-2018 eğitim öğretim yılında İhsan Doğramacı Uygulama Anaokulu ve Mevlana Anaokulu'nda eğitim alan; 22 deney, 24 kontrol grubu olmak üzere 48-66 aylık 46 çocuk oluşturmaktadır.

Araştırmanın çalışma grubunu oluşturan Selçuk Üniversitesi İhsan Doğramacı Uygulama Anaokulunda Montessori eğitimi alan 22 çocuk ve Mevlana Anaokulunda MEB O.Ö.E. programı uygulanan 24 çocuk, daha önce Montessori eğitimi almamış olmasına, 48-66 ay arasında olmasına ve normal gelişim göstermesine dikkat edilerek evrenden uygun örnekleme yöntemi ile seçilmiştir. Deney grubu çocuklarının 13 (\%59.1) 'ü kız, 9 (\%40.9)'u erkek ve \%59.1'i 4 yaş, \%40.9'u 5 yaştır. Deney grubu çocukların annelerinden, lisans mezunu olanlar grubun \%40.9'unu, lisansüstü mezunu olanlar grubun \%59.1'ini ve lisans mezunu babalar grubun \%59.1'ini, lisansüstü mezun babalar grubun \%40.9'unu oluşturmaktadır. Kontrol grubu çocuklarının ise 13 (\%54.2)'ü kız, $11(\% 45.8)$ 'i erkek ve \%41.7'si 4 yaş, \%58.3'ü 5 yaştır. Kontrol grubu çocukların babalarından, ilkokul mezunu olanlar grubun \%4.2'sini, lise mezunu olanlar grubun \%8.3'ünü, lisans mezunu olanlar grubun $\% 45.8$ 'ini, lisansüstü mezun olanlar grubun \%41.7'sini ve lise mezunu anneler grubun \%12.5'ini, lisans mezunu anneler grubun \%58.3'ünü, lisansüstü mezunu anneler grubun \%29.2'sini oluşturmaktadır.

\section{Veri Toplama Aracı}

Araştırmada veri toplama aracı olarak çalışma grubuna alınan çocuklar ve anne-babaları hakkında bilgi edinmek için kişisel bilgi formu ve çocukların bilimsel süreç beceri düzeylerini belirlemek için Aydoğdu ve Karakuş (2017) tarafindan geliştirilmiş "Okul öncesi Öğrencilerine Yönelik Temel Beceri Ölçeği” kullanılmıştır. Kişisel bilgi formu ile araştırma öncesinde deneysel süreç öncesinde grupların denkliği sağlayıp sağlamadığı kontrol edilmiştir. Okul Öncesi Öğrencilerine Yönelik Temel Beceri Ölçeği gözlem, sınıflama, çıkarım yapma, ölçme ve tahmin becerilerine yönelik 4'er soru olmak üzere toplamda 20 sorudan oluşan, güvenirlik katsayısı (KR20) 0.743 ve ortalama güçlüğü ise 0.69 olan bir ölçektir. Ayrıca her bir sorunun madde ayırt edicilik indeksinin 0.228 ile 0.558 arasındadır. Ölçekteki 20 sorunun da, üst ve alt grupta yer alan öğrencileri ayırt ettiği, okul öncesi öğrencilerinin temel becerilerini ölçmek için geliştirilen ölçeğin geçerli ve güvenilir bir ölçme aracı olduğu sonucuna ulaşılan ve okul öncesi öğrencilerinin bilimsel süreç becerilerini belirlemek amaciyla tasarlanan veri toplama aracı 3 şıkl bir kavram testidir. Testte yer alan maddelerin cevap seçenekleri, iki yanlış bir doğru maddeden oluşmaktadır. Çalışmaya katılan her çocuk verdiği her doğru cevap için 1 , yanlış cevap için ise 0 puan almıştır. Ölçekten alınabilecek en düşük puan 0 ve en yüksek puan 20'dir.

\section{Veri Toplama Süreci}

Veri toplama sürecinde araştırmaya dahil edilen deney ve kontrol grubu çocukların 20172018 eğitim-öğretim yılının kasım ayında araştırmacı tarafından ön test uygulaması gerçekleştirilmiştir. İsimleri önceden belirlenen çocuklara test hakkında kısa bir bilgilendirme yapıldıktan sonra test uygulama koşullarına elverişli bir sınıfta bireysel olarak uygulamaları yapılmıştır. Uygulama öncesinde araştırmacı her çocukla 3-5 dakika kadar iletişim kurarak, araştırmacıya 1sınmasını, rahatlamasını sağlamış ve ölçeği uygulamıştır. Ölçeğin bir çocuğa uygulama süresi ortalama 15 dakika sürmektedir. Son test uygulamaları da yine deney ve kontrol grubu çocukların 2017-2018 eğitim-öğretim yılının mart ayında araştırmacı tarafından tekrar aynı ölçek ve yöntemlerle gerçekleştirilmiştir. 


\section{Verilerin Analizi}

Bilimsel süreç becerilerini ölçmek amacıyla kullanılan, Okul Öncesi Öğrencilerine Yönelik Temel Beceri Ölçeği'nden elde edilen puanlar, parametrik test varsayımlarından olan verilerin normal dağılımı, varyansların homojenliği ve $\mathrm{n} \geq 20$ istatistiki açıdan test edilmiştir. Parametrik testler, belli bir dağılım ve parametreler esas alınarak geliştirildiği için bu sinırlılıklara bağlı olarak tanımlanmış temel varsayımlar içermekte ve ancak bu varsayımlar sağlandığında kullanılabilmektedir. Bir veya daha fazla varsayımın ihlal edilmesi durumunda test sonuçlarının hatalı ve yanıltıcı olacağından ötürü analizler öncesinde varsayımların incelenmesi önemlidir. Varsayımların sağlanıyor olması, aynı zamanda analiz sonuçlarının geçerliliğinin de bir kanıtıdır (Akt. Demir, Saatçioğlu ve İmrol, 2016). Gruplardan elde edilen verilerin normal dağılım gösterip göstermediği "basıklık ve çarpıklık katsayıları" ve "Kolmogorov-Smirnov testi" ile varyansların homojenliği ise "Levene's Test of Equality of Error Variances (Levene Hata Varyansları Eşitliği Testi)" ile incelenmiştir. Normalliği test etmek için aynı zamanda grafiklerde incelenmiştir. Veri setinin normallik testleri Kolmogorov-Smirnov ve Shapiro Wilk testlerine bakılarak anlaşılmaktadır. Gözlem sayısı 29'dan az olduğunda Shapiro Wilk, fazla olduğunda ise Kolmogorov-Smirnov (Lilliefors) testi kullanılmaktadır (Kalayc1, 2008,). Shapiro, Wilk ve Chen (1968) tarafindan yapılan bir simülasyon çalışmasında Shapiro-Wilk testinin normallik varsayımını değerlendirmek için kullanılmakta olan en güçlü test olduğu ortaya konulmuştur. Kolmogorov-Smirnov testinin ise örneklem büyüklüğü arttıkça gözlenen ve beklenen dağılımlar arasındaki küçük farkların manidar çıkma eğiliminde olması nedeni ile örneklem büyüklüğünden etkilendiği ve grafiksel veya betimsel yöntemlerle birlikte kullanılmasının gerektiği belirtilmektedir (Akt. Demir, Saatçioğlu ve İmrol, 2016).

Deney grubu ön test puanları için, Kolmogorov-Smirnov testi $(\mathrm{p}=.739)$, deney grubu son test puanları için, Kolmogorov-Smirnov testi $(\mathrm{p}=.771)$, kontrol grubu ön test puanları için, Kolmogorov-Smirnov testi $(\mathrm{p}=.427)$ ve kontrol grubu son test puanları için, Kolmogorov-Smirnov testi $(\mathrm{p}=.532)$ sonucunda $\mathrm{p}$ değerlerinin 0,05 'ten büyük olduğu sonucuna ulaşılmıştır. Bu sonuçlar doğrultusunda verilerin dağılımının normal olduğu söylenebilir. Çalışmada kullanılan veri setinin normal dağ 1 lım gösterip göstermediğinin incelenmesi için skewness (çarpıklık), kurtosis (basıklık) değerleri test edilmiştir. Deney grubu ön test puanları için skewness: ,149, kurtosis: -,716; deney grubu son test puanları için, skewness: -,049, kurtosis: -,780; kontrol grubu ön test puanları için skewness:,- 055 , kurtosis: ,582, ve kontrol grubu son test puanları için, skewness: 1,100 , kurtosis: 1,610 olduğunu. Normal dağılım gösteren bir veri setinin, çarpıklık ve basıklık değerlerinin -2 ile +2 arasında bulunması kabul edilebilir sınırlar arasında görülmektedir (George ve Mallery, 2016). Levene testi sonucunda da $p$ değerleri 0,05 'ten büyük olduğu için (deney ve kontrol grubu ön test puanları için, $\mathrm{p}=.693$ ve deney ve kontrol grubu son test puanları için, $\mathrm{p}=.568$ ) varyanslarının homojen olduğu söylenebilir. Yapılan analizlerden sonra verilerin normal dağılım gösterdiği gözlemlenmektedir. Bu nedenle deney ve kontrol gruplarının istatiksel farklılaşmasını ölçmek amacıyla parametrik testler kullanılmıştır. Cinsiyet değişkenine göre, deney ve kontrol grubu çocuklarının ön ve son test puan ortalamaları arasındaki fark, verilerin normal dağılması ve varyansların homojen olmasına rağmen, örneklem büyüklüğü ( $n \geq 20$ öncülünü sağlamadığından) küçük olduğu için grupların istatiksel farklılaşmasını değerlendirmek amacıyla non-parametrik testler kullanılmıştır.

Verilerin çözümlenmesinde, amaçlara uygun olarak tanımlayıcı istatistiksel teknikler (frekans, aritmetik ortalama, yüzdelik, standart sapma) kullanılmıştır. Çocukların aldığı Montessori eğitim programının, deney grubunda yer alan çocukların bilimsel süreç becerilerini etkileyip etkilemediğini saptamak için, deney grubu ve kontrol grubu çocukların ön test ve son test puanlarının farkının ortalamaları bağımsız gruplar için t testi ile karşılaştırılmıştır. Bağımsız gruplar için t-testi, iki gruba ait olan ortalamaların birbirinden farklı olup olmadığını test etmek amacıyla kullanılan bir istatistiksel yöntemdir (Büyüköztürk, 2011). Deney grubu çocuklarına verilen Montessori eğitim 
programı sonrası, bilimsel süreç becerileri ön test ve son test puan ortalamaları arasında farkın olup olmadığı ise bağımlı gruplar için t-testi ile sınanmıştır. Deney grubunda yer alan çocukların, cinsiyet değişkenine göre öntest ve sontest puan ortalamaları arasındaki farkı belirlemek amacıyla, iki bağımsız örneklemden elde edilen puanların birbirlerinden anlamlı bir şekilde farklılık gösterip göstermediğini test eden Mann-Whitney U testi (Büyüköztürk, 2011) kullanılmıştır. Aynı işlem kontrol grubunda yer alan çocuklar içinde tekrar edilmiştir.

\section{Bulgular}

Araştırmanın deney ve kontrol grubu çocuklarının ön test puan ortalamalarına ve son test puan ortalamalarına ilişkin bulgular Tablo 2 ve 3' te; kontrol grubu çocuklarının son test puan ortalamaları ile ön test puan ortalamalarına ilişkin bulgular Tablo 4' te; deney grubu çocuklarının son test puan ortalamaları ile ön test puan ortalamalarına ilişkin bulgular Tablo 5' te; kontrol grubu çocuklarının ve deney grubu çocuklarının cinsiyet değişkenine ilişkin ön test ve son test bulguları Tablo 6, 7, 8 ve 9' da yer almaktadır.

Tablo 2: Deney ve Kontrol Grubu Çocuklarının Okul Öncesi Öğrencilerine Yönelik Temel Beceri Ölçeği Ön Test Puanlarının Betimleyici İstatistik Sonuçları

\begin{tabular}{ccccccc}
\hline Ön Test & $\mathrm{n}$ & $\overline{\mathrm{x}}$ & $\mathrm{ss}$ & $\mathrm{t}$ & $\mathrm{df}$ & $\mathrm{p}$ \\
\hline Deney Grubu & 22 & 12.27 & 1.98 & .225 & 44 & .823 \\
Kontrol Grubu & 24 & 12.41 & 2.32 & & & \\
\hline
\end{tabular}

Tablo 2 incelendiğinde, deney ve kontrol gruplarının Temel Beceri Ölçeği’nden elde edilen ön test puan ortalamalarının anlamlı bir farklılık gösterip göstermediğini belirlemek amacıyla yapılan bağımsız grup t-testi sonucunda, gruplar arasında istatistiksel olarak anlamlı bir fark ( $\mathrm{p}=0.823>0.05)$ görülmemektedir. Montessori Yöntemi ile okul öncesi eğitim alan deney grubu çocuklarının Temel Beceri Ölçeği ön test puan ortalamaları ile M.E.B. Okul Öncesi Eğitim Programı kullanılarak okul öncesi eğitim alan kontrol grubu çocuklarının Temel Beceri Ölçeği ön test puan ortalamalarının benzer olduğu gözlenmektedir.

Tablo 3: Deney ve Kontrol Grubu Çocuklarının Okul Öncesi Öğrencilerine Yönelik Temel Beceri Ölçeği Son Test Puanlarının Betimleyici İstatistik Sonuçları

\begin{tabular}{ccccccc}
\hline Son Test & $\mathrm{n}$ & $\overline{\mathrm{x}}$ & $\mathrm{ss}$ & $\mathrm{t}$ & $\mathrm{df}$ & $\mathrm{p}$ \\
\hline Deney Grubu & 22 & 15.18 & 1.68 & -5.467 & 44 & .000 \\
Kontrol Grubu & 24 & 12.12 & 2.07 & & & \\
\hline
\end{tabular}

Tablo 3 incelendiğinde, deney ve kontrol gruplarının Temel Beceri Ölçeği’nden elde edilen son test puan ortalamalarının anlamlı bir farklılık gösterip göstermediğini belirlemek amacıyla yapılan bağımsız grup t-testi sonucunda, gruplar arasında deney grubu lehine istatistiksel açıdan $(p=0.000<0.05)$ anlamlı bir farklılık saptanmıştır. Montessori Yöntemi ile okul öncesi eğitim alan deney grubu çocuklarının Temel Beceri Ölçeği son test puan ortalamalarının, M.E.B. Okul Öncesi Eğitim Programı kullanılarak okul öncesi eğitim alan kontrol grubu çocuklarının Temel Beceri Ölçeği son test puan ortalamalarından daha yüksek olduğu gözlenmektedir. 
Tablo 4: Kontrol Grubu Çocuklarının Okul Öncesi Öğrencilerine Yönelik Temel Beceri Ölçeği Öntest-Sontest Puanlarının Betimleyici İstatistik Sonuçları

\begin{tabular}{ccccccc}
\hline Kontrol Grubu & $\mathrm{n}$ & $\overline{\mathrm{x}}$ & $\mathrm{ss}$ & $\mathrm{t}$ & $\mathrm{df}$ & $\mathrm{p}$ \\
\hline Ön Test & 24 & 12.41 & 2.32 & .550 & 23 & .587 \\
Son Test & 24 & 12.12 & 2.07 & & & \\
\hline
\end{tabular}

Tablo 4 incelendiğinde, kontrol grubu çocuklarının Temel Beceri Ölçeği ön test ve son test puan ortalamalarının anlamlı bir farklılık gösterip göstermediğini belirlemek amacıyla yapılan bağımlı grup t-testi sonucunda, aritmetik ortalamalar arasındaki fark istatistiksel $\operatorname{olarak}(\mathrm{p}=0.587>0.05)$ anlamlı bulunmamıştır.

Tablo 5: Deney Grubu Çocuklarının Okul Öncesi Öğrencilerine Yönelik Temel Beceri Ölçeği Öntest-Sontest Puanlarının Betimleyici İstatistik Sonuçları

\begin{tabular}{ccccccc}
\hline Deney Grubu & $\mathrm{n}$ & $\overline{\mathrm{x}}$ & $\mathrm{ss}$ & $\mathrm{t}$ & $\mathrm{df}$ & $\mathrm{p}$ \\
\hline Ön Test & 22 & 12.27 & 1.98 & -5.531 & 21 & .000 \\
Son Test & 22 & 15.18 & 1.68 & & & \\
\hline
\end{tabular}

Tablo 5 incelendiğinde, deney grubu çocuklarının Temel Beceri Ölçeği ön test ve son test puan ortalamalarının anlamlı bir farklılık gösterip göstermediğini belirlemek amacıyla yapılan bağımlı grup t-testi sonucunda, gruplar arasında son test lehine istatistiksel açıdan $(p=0.000<0.05)$ anlamlı bir farklılık saptanmıştır.

Tablo 6: Kontrol Grubu Çocuklarının Cinsiyet Değişkeni Açısından Okul Öncesi Öğrencilerine Yönelik Temel Beceri Ölçeği Ön Test Puanlarının Betimleyici İstatistik Sonuçları

\begin{tabular}{ccccccc}
\hline Kontrol Grubu Ön Test & $\mathrm{n}$ & $\mathrm{SO}$ & $\mathrm{ST}$ & $\mathrm{U}$ & $\mathrm{z}$ & $\mathrm{p}$ \\
\hline K1z & 13 & 13.23 & 172.00 & 62.00 & -.559 & .576 \\
Erkek & 11 & 11.64 & 128.00 & & & \\
\hline
\end{tabular}

Tablo 6 incelendiğinde, kontrol grubu çocuklarının Okul Öncesi Öğrencilerine Yönelik Temel Beceri Ölçeği’nden almış oldukları ön test puanlarının cinsiyet değişkenine göre anlamlı bir şekilde farklılaşıp farklılaşmadığını belirlemek üzere yapılan non-parametrik Mann Whitney-U testi sonucunda, gruplar arasında istatistiksel olarak anlamlı bir fark $(\mathrm{p}=0.576>0.05)$ görülmemektedir.

Tablo 7: Deney Grubu Çocuklarının Cinsiyet Değişkeni Açısından Okul Öncesi Öğrencilerine Yönelik Temel Beceri Ölçeği Ön Test Puanlarının Betimleyici İstatistik Sonuçları

\begin{tabular}{ccccccc}
\hline Deney Grubu Ön Test & $\mathrm{n}$ & $\mathrm{SO}$ & $\mathrm{ST}$ & $\mathrm{U}$ & $\mathrm{z}$ & $\mathrm{p}$ \\
\hline K1z & 13 & 11.15 & 145.00 & 54.00 & -.304 & .761 \\
Erkek & 9 & 12.00 & 108.00 & & & \\
\hline
\end{tabular}

Tablo 7 incelendiğinde, deney grubu çocuklarının Okul Öncesi Öğrencilerine Yönelik Temel Beceri Ölçeği'nden almış oldukları ön test puanlarının cinsiyet değişkenine göre anlamlı bir şekilde farklılaşıp farklılaşmadığını belirlemek üzere yapılan non-parametrik Mann Whitney-U testi sonucunda, gruplar arasında istatistiksel olarak anlamlı bir fark $(\mathrm{p}=0.761>0.05)$ görülmemektedir. 
Tablo 8: Kontrol Grubu Çocuklarının Cinsiyet Değişkeni Açısından Okul Öncesi Öğrencilerine Yönelik Temel Beceri Ölçeği Son Test Puanlarının Betimleyici İstatistik Sonuçları

\begin{tabular}{ccccccc}
\hline Kontrol Grubu Son Test & $\mathrm{n}$ & $\mathrm{SO}$ & $\mathrm{ST}$ & $\mathrm{U}$ & $\mathrm{z}$ & $\mathrm{p}$ \\
\hline Kiz & 13 & 13.50 & 175.50 & 58.50 & -.765 & .444 \\
Erkek & 11 & 11.32 & 124.50 & & & \\
\hline
\end{tabular}

Tablo 8 incelendiğinde, kontrol grubu çocuklarının Okul Öncesi Öğrencilerine Yönelik Temel Beceri Ölçeği'nden almış oldukları son test puanlarının cinsiyet değişkenine göre anlamlı bir şekilde farklılaşıp farklılaşmadığını belirlemek üzere yapılan non-parametrik Mann Whitney-U testi sonucunda, gruplar arasında istatistiksel olarak anlamlı bir fark $(\mathrm{p}=0.444>0.05)$ görülmemektedir.

Tablo 9: Deney Grubu Çocuklarının Cinsiyet Değişkeni Açısından Okul Öncesi Öğrencilerine Yönelik Temel Beceri Ölçeği Son Test Puanlarının Betimleyici İstatistik Sonuçları

\begin{tabular}{ccccccc}
\hline Deney Grubu Son Test & $\mathrm{n}$ & $\mathrm{SO}$ & $\mathrm{ST}$ & $\mathrm{U}$ & $\mathrm{z}$ & $\mathrm{p}$ \\
\hline Kiz & 13 & 9.00 & 117.00 & 26.00 & -2.201 & .028 \\
Erkek & 9 & 15.11 & 136.00 & & & \\
\hline
\end{tabular}

Tablo 9 incelendiğinde, deney grubu çocuklarının Okul Öncesi Öğrencilerine Yönelik Temel Beceri Ölçeği'nden almış oldukları son test puanlarının cinsiyet değişkenine göre anlamlı bir şekilde farklılaşıp farklılaşmadığını belirlemek üzere yapılan non-parametrik Mann Whitney-U testi sonucunda, gruplar arasında erkek çocuklarının lehine istatistiksel açıdan $(\mathrm{p}=0.028<0.05)$ anlamlı bir farkl11ık saptanmıştır.

\section{Tartışma ve Sonuç}

$\mathrm{Bu}$ araştırmada, Montessori yönteminin okul öncesi dönemdeki çocukların bilimsel süreç becerilerine etkisi incelenmiştir. Araştırma bulgularına göre deney grubu ve kontrol grubu çocukların ön test puan ortalamaları arasında anlamlı bir fark olmazken, son test puan ortalamaları arasında anlamlı fark olduğu bulunmuştur. Araştırma bulgularına göre, deney grubunda yer alan çocukların, ön test-son test puan ortalamaları arasındaki fark anlamlı iken kontrol grubunda yer alan çocukların, ön test-son test puan ortalamaları arasında anlamlı bir fark olmadığı bulunmuştur. Pepele Ünal (2006) çalışmasında, okul öncesi öğretmenlerinin fen eğitimine karşı tutumlarının çocukların bilimsel süreçleri kullanmalarında etkili olduğunu belirtmektedir. Tutumların davranışı etkilediği düşünüldüğünde, okul öncesi öğretmenlerinin fen eğitimine karş1 tutumlarının düşük olması, öğretme tarzları, etkinliği ele alma şekilleri ve materyal kullanım durumlarının birbirinden farklılığı, eğitim ortamında çocuklara bilim etkinliklerinin az veya yetersiz düzeyde gerçekleştirdiği söylenebilir. Erken yaşlarda bilimsel süreç becerilerini kazanması amacıyla hazırlanan programların çocuklara bu becerileri kazandırabilmede etkili ve kalıcı olduğu araştırma bulgusu Büyüktaşkapu (2010), Şahin, Güven ve Yurdatapan (2011), Özkan (2015), Tekerci (2015), Toprakkaya (2016), Yağcı (2016) araştırma bulguları ile tutarlılık göstermektedir.

Cinsiyet değişkenin bilimsel süreç becerileri üzerindeki etkisi incelendiğinde, deney grubunda yer alan çocukların ön test puan ortalamaları arasında anlamlı bir fark olmazken son test puan ortalamaları incelendiğinde erkek öğrencilerin puan ortalamalarının, kız öğrencilerin puan ortalamalarından anlamlı düzeyde yüksek olduğu bulunmuştur. Kontrol grubunda yer alan çocukların, cinsiyet değişkenine göre, ön test puan ortalamaları ve son test puan ortalamaları karşılaş̧ırıldığında puan ortalamaları arasında anlamlı bir fark olmadığı bulunmuştur. Konuyla ilgili alan yazında, farklı sonuçlara rastlamak mümkündür. Akman, Üstün ve Güler (2003), Aktaş Arnas, Gül Deretarla ve Sığırtmaç (2003), Ramazan ve Demir (2011), Turan (2012), Özkan (2015), Yağcı (2016), Alabay (2013) araştırma bulgularında çocukların bilimsel süreç becerilerinin ve fen eğitimine 
yönelik tutumlarının cinsiyete göre farklılaşmadığı görülmüştür. Leibham, Alexander ve Johnson (2013) küçük çocukların ilgi alanları ve ilgi duydukları bilimsel kavramların ilkokul dönemindeki akademik başarısına etkisinin cinsiyete göre etkisi araştırmak amacıyla yaptıkları çalışmada erkeklerin kızlardan daha yüksek seviyede bilimsel kavramlara ilgi gösterdiğini saptamışlardır. Ayrıca kızların 8 yaşında fen eğitimine dair ilgi alanlarının arttığı belirlenmiş ve erken ilgi alanlarının kızların ilerleyen öğretim kademelerindeki başarılarında belirleyici olduğunu yalnız erkeklerin ilerleyen öğretim kademeleri için bir yordayıcı olmadığı sonucuna ulaşılmıştır. Kunt (2016), okul öncesine devam eden 6 yaş çocukların bilimsel süreç beceri düzeylerini belirlemek ve farklı değişkenler açısından karşılaştırmak amacıyla yaptığı araştırmada cinsiyet durumları bakımından okul öncesi öğrencilerinin bilimsel süreç beceri alt boyutlarından aldıkları puanlar ölçme ve tahmin alt boyutlarında erkek öğrenciler lehine yüksek bulunurken diğer alt boyutlarda ise kı öğrenciler lehine yüksek bulunduğu sonucuna ulaşmıştır. Yücesan (2017) Montessori Eğitiminin okul öncesi dönem çocuklarının problem çözme becerileri ve problem davranışları üzerine etkisini incelediği araştırmasında çocukların problem çözme becerilerinin genel olarak cinsiyetlerinden anlamlı ölçüde etkilenmediği, soru sorma ve en uygun çözüm bulma konusunda erkeklerin kızlardan daha iyi düzeyde olduğu sonucuna ulaşmıştır.

Eğitimciler ve anne babalar için kaçırılmaması gereken bir firsat olan, insan hayatının diğer dönemlerinin temelini oluşturan okul öncesi yıllar çocuğa sağlanacak eğitim ortamı ve eğitim programları ile gelecek nesillerin sağlam temellerde yetişmesi açısından önemlidir (Yağcı, 2016). Elde edilen bulgular 1şığında Montessori Eğitim Programının bilimsel süreç becerilerinin gelişimine olumlu düzeyde etki ettiği görülmekle birlikte bilimsel süreç becerilerini geliştirip geliştirmediğine yönelik bilimsel çok fazla araştırma yapılmamış olması, bu çalışmanın ve elde edilen verilerin sonuçları bakımından daha da anlamlı olmasına imkân vermektedir.

\section{Öneriler}

Araştırmadan elde edilen veriler ışığında aşağıdaki öneriler sunulmuştur;

1.Literatür incelendiğinde Montessori Yönteminin okul öncesi dönemde bilimsel süreç becerilerine etkisini inceleyen yeterli çalışma olmadığı görülmüştür. Bu konuda yeni çalışmalar yapılması önerilebilir.

2.Bu araştırmada Montessori Eğitim Yönteminin okul öncesi dönem çocukların bilimsel süreç becerilerine etkisi incelenmiştir. Farklı programların bilimsel süreç becerilerine etkisi incelenebilir.

3.Okul öncesi dönemde farklı yaş gruplarıyla benzer çalışmalar uygulanarak bulgular değerlendirilebilir.

4.Araştırmayla alakalı yeni ölçme araçları geliştirilerek yeni çalışmalar yapılabilir.

5.Montessori yöntemi, mevcut okul öncesi eğitim müfredatında değerlendirilerek programın zenginleştirilmesine katkıda bulunulabilir.

6.Montessori eğitim felsefesi temele alınarak okul öncesi eğitim kurumlarında çalışan öğretmenlere bireysel ya da kurum eksenli eğitim etkinlikleri düzenlenebilir. Verilen eğitimler neticesinde de öğretmenlerin Montessori yönteminde olduğu gibi çocukların bireysel özelliklerini dikkate alarak bireyselleştirilmiş eğitime daha çok yer vermelerine olanak sağlanabilir.

7.Bu araştırmada, Montessori yönteminin bilimsel süreç becerilerinin gelişimine olumlu düzeyde etki ettiği sonucuna varılmıştır. Gelecekte yapılacak araştırmalarda takip çalışmalarına yer vererek, Montessori eğitim metodunun sonuçları derinlemesine incelenebilir. 
8.Okul öncesi eğitim öğretmenlerine çocukların bilimsel süreç becerilerini geliştirme ve desteklemelerine yönelik hizmet içi eğitim seminerleri verilebilir. Bu seminerler kapsamında Montessori Eğitim Yöntemi ve materyalleri de yer alabilir.

9.Okul öncesi öğretmenlerinin çocukların bilimsel süreç becerileri gelişimine ilişkin farkındalıklarını sağlamak ve yöntem bilgilerini artırmak ve yol gösterici olması için Montessori Eğitim Yöntemini temel alan bilimsel süreç becerilerini desteklemede kullanabilecekleri çalışmalar hakkında etkinlik örneklerinin sunulduğu kaynaklar düzenlenebilir.

\section{Kaynakça}

Akdeniz, Ö. (2017). Montessori yaklaşımının okul öncesi fen eğitiminde uygulanması. Yüksek Lisans Tezi. Yakın Doğu Üniversitesi, Eğitim Bilimleri Enstitüsü, Lefkoşa.

Akman, B., Üstün, E., ve Güler, T. (2003). 6 yaş çocuklarının bilim süreçlerini kullanma yetenekleri. Hacettepe Üniversitesi Eğitim Fakültesi Dergisi, 24(24), 11-14.

Aktaş Arnas, Y. (2003). Okul öncesi dönemde fen eğitiminin amaçları. Çocuk Gelişimi ve Eğitimi Dergisi, 6(7), 1-6.

Aktaş Arnas, Y., Gül Deretarla, E. ve Sığırtmaç, A. (2003). 48-86 ay çocuklar için sayı ve işlem kavramları testinin geçerlilik ve güvenirlik çalışması. Çukurova Üniversitesi Sosyal Bilimler Enstitüsü Dergisi, 12(12) 147-157.

Alabay, E. (2013). Sciencestart destekli fen eğitim programının 60-72 aylık çocukların bilimsel süreç becerilerine ve bilimsel tutuma güvenme ve yönelime etkisi. Yayımlanmamış doktora tezi. Selçuk Üniversitesi, Sosyal Bilimler Enstitüsü, Konya. https://doi.org/10.16986/huje.2018037123

Arı, R. (2005). Eğitim psikolojisi (4. Basım). Ankara: Nobel Yayın Dağıtım.

Aydoğdu, B. ve Karakuş, F. (2017). Okul öncesi öğrencilerinin temel becerileri: Bir ölçek geliştirme çalışması. Kuramsal Eğitimbilim Dergisi, 10(1), 49-72. https://doi.org/10.5578/keg.10767

Ayvacı, H. Ş. (2010). Okul öncesi dönem çocuklarının bilimsel süreç becerilerini kullanma yeterliliklerini geliştirmeye yönelik pilot bir çalışma. Necatibey Eğitim Fakültesi Elektronik Fen ve Matematik Eğitimi Dergisi, 4(2), 1-24. https://doi.org/10.17522/balikesirnef.278430

Ayvac1, H. S., Devecioğlu, Y. ve Yiğit, N. (2002). Okul öncesi ögretmenlerinin fen ve doğa etkinliklerindeki yeterliliklerinin belirlenmesi. V. Ulusal Fen Bilimleri ve Matematik Eğitimi Kongresi, 16-18 Eylül 2002, ODTU Kültür ve Kongre Merkezi, Ankara.

Bağc1-Kılıç, G. (2003). Üçüncü uluslararası matematik ve fen araştırması (TIMSS): fen öğretimi, bilimsel araştırma ve bilimin doğası. İlköğretim Online, 2(1), 42-51.

Büyüköztürk, Ş. (2011). Sosyal bilimler için veri analizi el kitabı. Ankara: Pegem Akademi. https://doi.org/10.14527/9789756802748

Büyüktaşkapu, S. (2010). 6 yaş çocuklarının bilimsel süreç becerilerini geliştirmeye yönelik yapılandırmacı yaklaşıma dayalı bir bilim öğretim programı önerisi. Yayımlanmamış doktora tezi. Selçuk Üniversitesi, Sosyal Bilimler Enstitüsü, Konya.

Büyüktaşkapu, S. (2012). Montessori yaklaşımı ve okul öncesinde fen eğitimi. TÜBAV Bilim Dergisi, $5(3), 19-25$.

Büyüktaşkapu, S., Çeliköz, N. ve Akman, B. (2012). Yapılandırmacı bilim eğitimi programı'nın 6 yaş çocuklarının bilimsel süreç becerilerine etkisi. Eğitim ve Bilim, 37(165), 275-292. 
Demir, E., Saatçioğlu, Ö., ve İmrol, F. (2016). Uluslararası dergilerde yayımlanan eğitim araştırmalarının normallik varsayımları açısından incelenmesi. Current Research in Education, 2(3), 130-148.

George, D. ve Mallery P. (2016). IBM SPSS statistics 23 step by step: A simple guide and reference. New York, NY: Routledge

Grazzini, C. (2013). Maria Montessori's cosmic vision, cosmic plan, and cosmic education. The NAMTA Journal, 38 (1) , 107-116.

Kalayc1, Ş. (2008). SPSS uygulamalı çok değişkenli istatistik teknikleri. Ankara: Asil Yayın Dağıtım.

Karasar, N. (2009). Bilimsel araştırma yöntemi (19. Baskı) . Ankara: Nobel Yayın Dağııım.

Kefi, S., Çeliköz, N. ve Erişen, Y. (2013). Okul öncesi eğitim öğretmenlerinin temel bilimsel süreç becerilerini kullanım düzeyleri. Eğitim ve ögretim araştırmaları dergisi, 2(2), 300-319.

Kefi S. ve Uslu, M. (2015). The effects of supportive scientific activities education program on preschool teachers' usage levels of basic scientific process skills. Middle-East Journal of Scientific Research, 23 (11), 2619-2626.

Kılıç, Ş. (2010). Çocukların bilime ve bilim insanına yönelik tutumları ve kalıplaşmış yargıları. Türk Ĕ̈itim Bilimleri Dergisi, 8(2), 439-455.

Kula, G. (2011). Okul öncesi eğitiminin 9., 10. ve 11. sinıf öğrencilerinin bilimsel süreç becerilerine etkisi: Polatlı ilçesi örneği. Yayımlanmamış yüksek lisans tezi. Gazi Üniversitesi, Eğitim Bilimleri Enstitüsü, Ankara.

Kunt, B. (2016). 60-72 ay okul öncesi öğrencilerinin bilimsel süreç becerilerinin belirlenmesi. Yayımlanmamış yüksek lisans tezi. Dumlupınar Üniversitesi, Eğitim Bilimleri Enstitüsü, Kütahya.

Kuru, N. ve Akman, B. (2017). Okul öncesi dönem çocuklarının bilimsel süreç becerilerinin öğretmen ve çocuk değişkenleri açısından incelenmesi. Ĕgitim ve Bilim, 42(190), 269-279.

Leibham, M.B., Alexander, J.M. ve Johnson, K.E. (2013). Science interests in preschool boys and girls: relations to later self-concept and science achievement. Science Education, 97(4), 574593. https://doi.org/10.1002/sce.21066

Murpy, C. ve Smith, G. (2014). The impact of a curriculum course on pre-service primary teachers' science content knowledge and attitudes towards teaching science. Irish Educational Studies, 31(1), 77-95. https://doi.org/10.1080/03323315.2011.634061

O'Donnell, M. (2014). Maria Montessori. Bloomsbury Academic [Google Books versiyonu]. Erişim adresi:https://books.google.com.tr/books?id=JFKCBAAAQBAJ\&pg=PA67\&lpg=PA67\&d $\mathrm{q}=$ Cosmic + plan + montessori\&source $=$ bl\&ots $=$ MloV-WyPSj\&sig=ACfU3U3En-

rQvY19yrj_fw57KFM0sxDgdw\&hl=tr\&sa=X\&ved=2ahUKEwiKhYSJ_foAhVChRoKHZsNCdUQ6AEwEXoECAsQKw\#v=onepage\&q=Cosmic\%20plan\%20m ontessori\&f=false

Özbey, S. ve Alisinanoğlu, F. (2009). Okul öncesi eğitim kurumlarında görev yapan öğretmenlerin fen etkinliklerine ilişkin yeterlikliklerinin bazı değişkenlere göre incelenmesi. Gazi University Journal of Gazi Educational Faculty (GUJGEF), 29(1), 1-18.

Özdağ, S. A. (2014). Montessori metodunun eğitim mekanlarına yansiması üzerine kavramsal bir analiz. Yayımlanmamış yüksek lisans tezi. Karadeniz Teknik Üniversitesi, Fen Bilimleri Enstitüsü, Trabzon. 
Özkan, B. (2015). 60-72 ayllk çocuklar için bilimsel süreç becerileri ölçeğinin gelişstirilmesi ve beyin temelli ögrenmeye dayanan fen programının bilimsel süreç becerilerine etkisi. Yayımlanmamış yüksek lisans tezi. Marmara Üniversitesi, Eğitim Bilimleri Enstitüsü, İstanbul. https://doi.org/10.16991/inesjournal.285

Pepele Ünal, M. (2006). Okul öncesi öğretmenlerinin fen eğitimine karşı gösterdikleri tutumların çocukların fen süreçlerini kullanmalarına etkisinin incelenmesi; Ankara-Malatya illeri örnekleri. Yayımlanmamış yüksek lisans tezi. İnönü Üniversitesi, Sosyal Bilimler Enstitüsü, Malatya.

Ramazan, O. ve Demir, S. (2011). Okul öncesi eğitim kurumuna devam eden 36-48 aylık çocukların bilişsel gelişim düzeyleri. Ĕgitim Bilimleri Araştırma Dergisi, 1(2), 83-98.

Saçkes, M., Akman, B. and Trundle, C. K. (2012). A science methods course for early childhood teachers: a model for undergraduate pre-service teacher education. Necatibey Ĕgitim Fakültesi Elektronik Fen ve Matematik Eğitimi Dergisi, 6(2), 1-26. https://doi.org/10.12973/nefmed

Şahin, F., Güven, İ. ve Yurdatapan, M. (2011). Proje tabanlı eğitim uygulamalarının okul öncesi çocuklarında bilimsel süreç becerilerinin gelişimine etkisi. M. Ü. Atatürk Ĕgitim Fakültesi Ĕ̈itim Bilimleri Dergisi, 33, 157-176.

Şahintürk, Ö. (2012). Montessori yönteminin okul öncesi dönemde öğrencilerin yaratıcl düsünmelerine etkisi. Yayımlanmamış yüksek lisans tezi. Karaelmas Üniversitesi, Sosyal Bilimler Enstitüsü, Zonguldak

Tan, M. ve Temiz, B. K. (2003). Fen öğretiminde bilimsel süreç becerilerinin yeri ve önemi. Pamukkale Üniversitesi Eğitim Fakültesi Dergisi, 13(13), 89-101.

Tekerci, H. (2015). 60-66 aylık çocukların bilimsel süreç becerilerine duyu temelli bilim eğitimi programının etkisi. Yayımlanmamış doktora tezi. Gazi Üniversitesi, Eğitim Bilimleri Enstitüsü, Ankara.

Temel, Z. F. ve Toran, M. (2013). Montessori eğitim yöntemi. Z. F. Temel (Editör). Erken çocukluk eğitiminde yaklaşımlar ve programlar (2. baskı) içinde (s. 143-190). Ankara: Vize Yayıncilik.

Toprakkaya, İ. M. (2016). 55-72 aylık çocuklara dış alanda uygulanan sorgulama tabanlı bilim etkinliklerinin bilimsel süreç becerilerine etkisinin incelenmesi. Yayımlanmamış yüksek lisans tezi. Okan Üniversitesi, Sosyal Bilimler Enstitüsü, İstanbul.

Turan, G. S. (2012). Okul öncesi çocukları için bilimsel süreç becerilerini değerlendirme aracının geliştirilmesi. Yayımlanmamış yüksek lisans tezi. Gazi Üniversitesi, Eğitim Bilimleri Enstitüsü, Ankara.

Ünal, M. ve Akman, B (2006). Okul öncesi öğretmenlerinin fen eğitimine karşı gösterdikleri tutumlar. Hacettepe Üniversitesi Ĕ̈itim Fakültesi Dergisi, 30(30), 251-257.

Yağc1, M. (2016). Okul öncesi dönem çocuklarının bilimsel süreç becerilerinin gelişmesinde doğa ve çevre uygulamalarının etkisinin incelenmesi. Yayımlanmamış yüksek lisans tezi. Abant İzzet Baysal Üniversitesi, Eğitim Bilimleri Enstitüsü, Bolu.

Yücesan, Y. (2017). Montessori eğitiminin okul öncesi dönem çocukların problem çözme becerileri ve problem davranışları üzerine etkisinin incelenmesi. Yayımlanmamış yüksek lisans tezi. Karabük Üniversitesi, Sağlık Bilimleri Enstitüsü, Karabük. 